\title{
Strategic R\&D Location by Multinational Firms: Spillovers, Technology Sourcing, and Competition
}

\author{
RENÉ BELDERBOS \\ Katholieke Universiteit Leuven and Eindhoven University of Technology \\ ELISSAVET LYKOGIANNI \\ Katholieke Universiteit Leuven \\ REINHILDE VEUGELERS* \\ EC-DGECFIN, Katholieke Universiteit Leuven and CEPR
}

\begin{abstract}
We analyze strategic interaction in R\&D internationalization decisions by two multinational firms competing both abroad and in their home markets and examine different incentives for foreign R\&D faced by technology leaders and technology laggards. The model takes into account the impact of local inter-firm R\&D spillovers, (non-costless) international intra-firm transfer of knowledge, and the notion that internal R\&D increases the effectiveness of incoming spillovers. Greater efficiency of intra-firm transfers and greater spillovers increases the attractiveness of home R\&D to the technology leader. The lagging firm in contrast increases the share of foreign $\mathrm{R} \& \mathrm{D}$ as overseas technology sourcing becomes more effective. Greater product market competition encourages the leading firm to engage in foreign $R \& D$ to capture a larger share of profits on the foreign market, while laggards concentrate more $\mathrm{R} \& \mathrm{D}$ at home to defend their home market position. The country with a stricter intellectual property rights regime attracts a larger shares of R\&D by both leader and laggard.
\end{abstract}

Keywords: MNEs, R\&D, R\&D spillovers

JEL classification: D21, F23, L16

* Corresponding Author: KUL-FETEW, Naamsestraat 69, 3000 Leuven, Belgium; E-mail: Reinhilde.Veugelers@econ.kuleuven.ac.be; Tel: 32-16-32 69 08; Fax: 32-16-32 6732

The authors are grateful for the comments received from C. Altomonte, F. Sanna-Randaccio, and participants at the EIBA 2004 conference and a seminar at the KU Leuven. The authors acknowledge support from KU Leuven grant OT/04/07A. Veugelers acknowledges support from the Belgian Federal Government DWTC (IUAP P5/11/33) and the Flemish Government (SOOS). 


\section{Introduction}

The internationalization of $R \& D$ by multinational firms has been a growing phenomenon in the last two decades. With a global business environment where the pace and scope of changes in technological know-how and consumer taste are unprecedented, managing the innovative process on a global scale has become more central in today's multinational corporations: sensing new market and technology trends worldwide, while adequately responding to them through generating new ideas which are then implemented on a global scale. These tendencies imply changes in the governance of innovations in multinational companies, with a more pivotal role for subsidiaries in developing global innovations. Where firms will locate $R \& D$ activities is nowadays more driven by a global technology sourcing need to develop interactions with the local systems of technological competence and end users. This new phenomenon has implications for policy makers of both net recipient and net source countries, who are concerned that the internationalization of R\&D may erode ("hollow out") their knowledge base. However, although the existence of the phenomenon is generally accepted, its importance, driving forces, and impact are not yet clearly understood (OECD 2005).

An increasing number of empirical studies have examined which firm and host country characteristics affect foreign R\&D (e.g. Kuemmerle 1997; Florida 1997; Belderbos, 2001; 2003; Kuemmerle, 1999; von Zedtwitz and Gassman, 2002; Odagiri and Yasuda, 1999; Zejan, 1990; Kumar 1996; Chung and Alcacer, 2002). These studies have suggested that foreign R\&D is motivated both by the need to exploit and adapt the investing firms' technology to local demand and manufacturing conditions, as well as the need to get access to local science and technology resources (technology sourcing). Although the exploitation motive has long 
been dominant, the evidence suggests that the technology sourcing motive is becoming a major force (Kuemmerle, 1999; Griffith et al, 2003).

In an attempt to better understand the determinants and effects of $R \& D$ decentralization decisions, recent theoretical studies have examined the incentives to locate R\&D abroad. These studies have mainly taken the perspective of a single multinational firm, treating domestic and foreign rival firms as a competitive fringe and thus ignoring strategic interaction among competing MNEs (Norback, 2001; Sanna-Randaccio and Veugelers, 2002). Other contributions have been more concerned with the type of research being allocated overseas (Franck and Owen, 2003), the geography of R\&D and manufacturing within countries (Gersbach and Schmutzler, 1999), or with strategic FDI rather than R\&D investments (Siotis, 1999, Bjorvatn and Eckel, 2001).

In this paper, we examine the strategic interaction between $R \& D$ localization decisions of two multinational firms based in different countries, operating affiliates in each other's home markets. The decision to allocate $R \& D$ abroad has an impact on the $R \& D$ decisions of a rival multinational, who will determine its best response. The intensity of this strategic interaction in R\&D localization between the two multinational firms depends on the degree of product market competition. We examine the different incentives faced by technology leaders and technology laggards in the decision to locate R\&D abroad. R\&D localization, by influencing the scope for intra-firm international knowledge transfers and inter-firm knowledge spillovers, impacts the effective knowledge base of the firms in home and host markets. The model allows both motivations for overseas R\&D: to improve foreign affiliate profitability by adapting processes and products to local circumstances and to source knowledge from the local foreign rival. It considers both 'faces of R\&D': a positive impact on the firm's knowledge base as well as a positive impact on the effectiveness of knowledge sourcing from external sources (i.e. the firm's absorptive capacity) ${ }^{1}$. Scale economies in the 
R\&D process (e.g. Kuemmerle, 1999) provide a disincentive to R\&D internationalization, while international knowledge transfer neither is costless. The equilibrium share of R\&D located abroad depends on the international knowledge transfer efficiency, the extent of external spillovers related to countries' intellectual property rights protection (IPR) regimes, and the degree of product market competition.

The remainder of this paper is organized as follows. Section 2 gives a brief overview of the relevant literature to provide background to the formulation of the model of strategic $R \& D$ localization. Section 3 describes the basic model and Section 4 analyzes the impact of the main parameters of interest on the optimal allocation of R\&D. Section 5 concludes.

\section{Background}

In many OECD countries (e.g. thee US, France and the UK), the share of foreign affiliates in $R \& D$ is smaller than their share in manufacturing production, demonstrating that R\&D activities are still less internationalized than manufacturing activities. Nevertheless, the percentage of $R \& D$ carried out abroad is increasing rapidly. $R \& D$ expenditures by foreign affiliates increased by more than 50\% in the OECD area between 1991 and 2001 (OECD, 2005). Slaughter (2004) shows that the share of total R\&D in the US performed by wholly owned non-bank subsidiaries has grown from 9.2 percent of total US R\&D in 1992 to 14.4 percent in 2002. For Japanese multinational firms, reported overseas R\&D in a survey by Japan's Ministry of Economics, Trade, and Industry stood at 279 billion Yen in 1997 increasing to 411 billion Yen in 2002. Despite this growth, the ratio of overseas to domestic R\&D only reached 4.1 percent in 2002. At the firm level, Gassman and von Zedtwitz (2002) 
find substantially higher foreign $R \& D$ ratios for leading multinational firms, especially from smaller EU economies.

In an attempt to explain the growing phenomenon of internationalization of $R \& D$, a number of empirical studies, often based on surveys and case-studies, have investigated into more detail the (changes in) firms' motivations in carrying out R\&D abroad and the specific R\&D activities that are performed abroad. This literature (e.g. Kuemmerle 1997, Florida 1997, Reger 2001, Le Bas and Sierra 2002, Odagiri and Yasuda, 2003) suggests that whereas traditionally overseas $R \& D$ was conducted to adapt home-developed technologies to foreign markets ('home base exploiting' $R \& D$ ), foreign $R \& D$ activities are now becoming more important vehicles to access local technological expertise abroad and to create new technologies that can be used in all the MNE's markets ('home base augmenting' R\&D). A number of studies have analyzed the R\&D expenditures by foreign affiliates of MNEs to examine which countries are most likely to attract foreign R\&D (Zejan,1990; Fors, 1996; Kumar, 2001;Odagiri \& Yasuda, 1996; Belderbos, 2001, 2003; Chung and Alcacer, 2002). $\mathrm{R} \& \mathrm{D}$ is found to be attracted to larger local markets and markets with high per capita income, and to follow MNEs' manufacturing and sales activities, reflecting technology exploitation motives. R\&D activities are also located in countries with an abundance of scientists and engineers and a technological lead in the industry of the investing firm, reflecting technology sourcing motives. Japanese firms in particular, have been found to use joint ventures and acquisitions relatively frequently to build up effective overseas R\&D bases more rapidly, with technologically lagging firms most active in this regard (e.g. Belderbos, 2003; Belderbos et al., 2005).

The growing importance of 'technology sourcing' strategies, where affiliate R\&D is used as vehicle to access local technological expertise abroad, is also confirmed by studies analyzing patent citation data ${ }^{2}$. Almeida (1996) analyses the citations contained in a sample 
of patents granted by the USPTO to MNEs in the US semiconductor industry and finds that foreign subsidiaries build upon localized sources of knowledge, since the patents cited by foreign affiliates are more likely to have originated in the US or in the same US State where they operate. Frost (2001) also confirmed that geographic proximity matters substantially for technology sourcing and spillovers: foreign firms' subsidiaries were found to cite research by other institutions and firms in the same US state relatively frequently. This is consistent with the finding of Branstetter (2000) that Japanese firms investing in the US have a significantly higher probability of citing other US firms' patents.

Internationalization of $\mathrm{R} \& \mathrm{D}$ also has implications for the internal knowledge flows between parents and subsidiaries. Knowledge flows from foreign units to the parent company will be more likely if foreign affiliates are undertaking 'home base' augmenting type of activities that generate knowledge valuable for the rest of the organization. The challenge for a globally innovating MNE is to effectively transfer locally acquired know-how across its units. Effective intra-firm knowledge diffusion requires 'dual embeddedness' on the part of the subsidiary, i.e. embeddedness in both external and in intra-firm networks' (Frost, 1998). Recent empirical evidence suggests that overseas R\&D geared towards technology sourcing has a positive impact on the productivity of parent operations (Iwasa and Odagiri, 2003; Griffith, Harrison \& van Reenen, 2003), suggesting effective reverse technology flows associated with technology sourcing R\&D-FDI.

A traditional factor favoring centralization of $R \& D$ at home rather than dispersing $R \& D$ abroad, beyond the classical economies of scale in $R \& D$ argument, is the greater risk of dissipation of know how to local competitors, the flip side of potential technology sourcing from local sources. As patent citation data show, foreign subsidiaries do not only acquire local know-how, they are also sources of knowledge spillovers to the local economy. Both Almeida (1996) and Branstetter (2000) provide evidence that patents belonging to foreign 
firms investing in the US are disproportionally US firms. Veugelers \& Cassiman (2002) using survey data from a sample of innovating Belgian firms confirm bi-directional knowledge transfers between foreign subsidiaries and local Belgian firms.

In particular when multinational firms are technology leaders and affiliates are located in countries with an insufficiently developed intellectual property rights protection regime, maintaining control over core technologies is a key issue and can discourage foreign $R \& D$. Branstetter et al (2003) provide evidence that R\&D by US firms with large patent portfolios is responsive to positive reforms in intellectual property rights protection regimes in host markets. Other studies have found that multinational firms adapt the type of activities located abroad in response to intellectual property rights concerns, with knowledge intensive and higher value added activities reserved for countries with stronger IPR regimes (Lee and Mansfield, 1996; Smarzynska, 2004). Zhao (2004) shows that foreign R\&D labs in China mostly engage in R\&D for technologies where the parent can maintain control over key complementary resources. Hence, overseas R\&D does not only provide sourcing opportunities, it may also increase the risk of dissipation of $R \& D$ results to foreign rivals, in particular when there are fewer possibilities to protect know how and intellectual property. The negative consequences of unintended outgoing knowledge spillovers will be greatest when the foreign rivals are direct competitors of the multinational in the host country product market, and even more so if the foreign rivals are also competing within the multinational's main markets.

There has been surprisingly little formal analysis of R\&D localization decisions by multinational firms. Norback (2001) develops a model of R\&D localization and foreign manufacturing investment by a single multinational firm. He finds that R\&D intensive firms are more likely to produce abroad, the lower the transfer costs of technology from the headquarters, and found empirical evidence for this in data on Swedish multinationals. Petit 
and Sanna-Randaccio (2000) study the interaction between R\&D investments and reciprocal foreign direct investment by multinational firms based in two countries, but do not allow for R\&D localization. The notion that establishing subsidiaries abroad leads to dissipation of know-how is developed in Ethier \& Markusen (1996) who find that MNE's may prefer exports over FDI to be better able to control knowledge flows. Similarly, Fosfuri (2000) analyses the MNE's choice between FDI, exports and licensing and the vintage of the technology transferred. ${ }^{3}$ Siotis (1999) develops a symmetric two-firm, two-country model where an MNE when serving the foreign market through FDI generates spillovers to local competitors, but will also be able to learn from local rivals. If the technology gap between the firms is large, the advanced firm prefers exports over FDI, while the technologically backward firm engages in FDI, which allows for technology sourcing. Bjorvatn and Eckel (2001) similarly model the export versus FDI choice for two firms based in different countries. The extent to which FDI is profitable depends on both the level of technology spillovers among the firms and the efficiency of technology transfers from affiliates to the headquarters. One finding is that a technological leader may invest strategically in the market of the follower in order to pre-empt knowledge sourcing FDI by the follower in the home country of the leader.

A more limited number of papers have more specifically modeled the geography of R\&D. Cadot and Desruelle (1998) are concerned with different location determinants of development and research activities. Firms located in smaller markets are, on average, less successful in transforming research outputs to products. This implies a pattern of international specialization in $R \& D$ activities according to which firms located in smaller countries do more research, while firms located in larger countries devote more resources to the development stage. Franck and Owen (2003) focus on the role of country-specific stocks of knowledge on R\&D localization. In case foreign and domestic knowledge stocks are 
substitutes, firms have fewer incentives to locate $R \& D$ in the foreign market, while the opposite holds when knowledge stocks are complementary. Gersbach and Schmutzler (1999) model a duopoly where firms have to decide on one specific location for their innovation activities, which may be the same or different from their manufacturing activities. They allow for both variation in internal transfers (due to transfer costs of knowledge from the location of innovation to the location of manufacturing) and geographically bounded external spillovers (from innovation to co-located manufacturing). In their model, which is more concerned with examining $R \& D$ agglomeration within a country than with international $R \& D$, they find that efficiency of internal transfers promotes agglomeration of innovation. Sanna-Randaccio and Veugelers (2002) also allow for internal and external (spillover) knowledge flows while considering the impact of foreign competition. Their analysis is limited to the internationalization decision of one multinational firm facing only competition from local firms, ignoring interaction effects with potential rival MNEs.

In this paper, we contribute to the literature by examining the strategic interaction between R\&D localization decisions of two multinationals based in different countries. The R\&D localization decisions depend on the efficiency of international intra-firm transfers, the extent of locally bounded inter-firm spillovers, and the degree of product market competition. We examine the asymmetry in incentives to locate $R \& D$ abroad for a technology leader and a technology laggard.

\section{A Model of Strategic R\&D Localization by Multinational Firms (MNEs)}

We develop a simple model of strategic interaction in R\&D localization decisions between two multinational firms based in different countries. Each multinational firm 
operates a subsidiary in the rival firm's home country and both multinationals are duopolists in the product market of each country, which are segmented markets. Both MNEs decide simultaneously what share of their R\&D resources to allocate to their foreign subsidiary rather than to the home R\&D site at headquarters ${ }^{4}$. This R\&D location decision has an impact on the effective knowledge base of the subsidiary and headquarters, and increases in this effective knowledge base positively affects subsidiary's and headquarters' profits, either by reducing costs or by expanding relative demand. The effective knowledge base consists of own $R \& D$ resources in the location, international intra-firm transfer of knowledge, and incoming external knowledge spillovers from local R\&D of the rival firm. Incoming external knowledge spillovers, however, are only possible if the firm has the capacity to absorb such spillovers, and hence require local $R \& D$.

\section{Profit Functions}

Let $\lambda_{i}$ denote the share of firm's $i$ R\&D resources allocated to that firm's subsidiary with $\lambda_{i} \in[0,1]$ and $i, j=1,2, i \neq j . \quad X_{1}$ and $X_{2}$ correspond to the level of firm's 1 and firm's 2 total R\&D resources respectively. Firm chooses the value of $\lambda_{i}$ that maximizes total profits (of subsidiary and headquarters), with the profit function given by:

$$
\Pi_{i}=\Pi_{i}^{P}\left(K_{i}^{P}, K_{j}^{S}\right)+\Pi_{i}^{S}\left(K_{i}^{S}, K_{j}^{P}\right)-\frac{\delta}{2}\left(\lambda_{i} X_{i}\right)^{2}
$$

where $K_{i}^{P}, K_{i}^{S}$ are the effective knowledge bases of firm $i$ located at the parent (headquarters) and overseas subsidiary; respectively, $K_{j}^{P}, K_{j}^{S}$ the knowledge bases of rival firm $j$. Profits in a country depend directly on the effective knowledge base the firm has in 
the country, as well as the knowledge bases of the rival firm. The knowledge bases are in turn a function of the $\mathrm{R} \& \mathrm{D}$ resources $\left(X_{i}, X_{j}\right)$ and the localization ratios $\left(\lambda_{i}, \lambda_{j}\right)$. Geographical dispersion of $R \& D$ is costly, since $R \& D$ is characterized by scale economies. This is captured by a quadratic cost function given by the last term of (1), with $\delta \in(0,1)$ reflecting the extent of the scale economy advantage given up when decentralizing R\&D.

The total marginal impact on profits of a change in the localization ratio $\lambda_{i}$ is:

$$
\frac{\partial \Pi_{i}}{\partial \lambda_{i}}=\frac{\partial \Pi_{i}}{\partial K_{i}^{P}} \frac{\partial K_{i}^{P}}{\partial \lambda_{i}}+\frac{\partial \Pi_{i}}{\partial K_{i}^{S}} \frac{\partial K_{i}^{S}}{\partial \lambda_{i}}+\frac{\partial \Pi_{i}}{\partial K_{j}^{P}} \frac{\partial K_{j}^{P}}{\partial \lambda_{i}}+\frac{\partial \Pi_{i}}{\partial K_{j}^{S}} \frac{\partial K_{j}^{S}}{\partial \lambda_{i}}-\delta \lambda_{i} X_{i}^{2}
$$

The change in localization affects the knowledge bases of the parent and the subsidiary but also the knowledge bases of parent and subsidiary of the rival firm. The impact on total profits depends on the marginal impact of own and rival firm's knowledge bases on profits and the marginal cost of decentralizing.

\section{The impact of knowledge bases on profits}

We first discuss how own and rival knowledge bases affect profits. Since our main focus is the impact of inter- and intra-firm knowledge flows on knowledge bases and R\&D localization decisions, we assume a simple fixed structure of the marginal impact of knowledge bases on profits, in order to keep the number of parameters in the model manageable.

$$
\frac{\partial \Pi_{i}}{\partial K_{i}^{P}}=\frac{\partial \Pi_{i}}{\partial K_{i}^{S}}=b
$$




$$
\frac{\partial \Pi_{i}}{\partial K_{j}^{P}}=\frac{\partial \Pi_{i}}{\partial K_{j}^{S}}=-\mu b
$$

The parameter $b$ captures the positive impact of an increase in the knowledge base, at headquarters or at the subsidiary, on total profits. The knowledge base influences profits positively either by reducing costs and/or enhancing demand. The parameter $b$ can reflect the size of the market as well the technological opportunities in the industry. For simplicity and because it is not the focus of our attention, we assume this parameter to be equal across firms and markets.

The knowledge base of the rival multinational reduces the relative cost or demand advantage of the firm and thus has a negative impact on the firm's profits, to the extent that firms are directly competing in product markets. The degree to which the rival firm's knowledge base impacts the firm's profits depends on the intensity of product market competition between the two firms. The parameter $\mu$ captures this intensity of product market competition, where we make the conventional assumption that the marginal impact of rival's knowledge bases on profits is smaller than the marginal impact of the own knowledge bases $(0<\mu<1)$. By letting the value of the parameter $\mu$ vary, we can analyze how results are affected by the intensity of rivalry between the MNEs due to different degrees in product differentiation.

\section{The composition of the knowledge bases}

Before we can analyze the firm's optimal localization decisions, we need to characterize the composition of the firm's effective knowledge bases, both at the parent and the subsidiary plant level. The effective knowledge base consists of three parts: 1) own R\&D resources, 2) internal knowledge transfers, and 3) external knowledge sourcing. 
With respect to own $R \& D$ resources, we allow the firms to differ in the size of their total own R\&D resources. Firm 1 is assumed to have larger $R \& D$ resources and is 'technology leader', while firm 2 is the technology 'laggard', i.e.: $X_{1}>X_{2}$. The relative technology lead of the leader, denoted by the parameter $s$, represents the 'laggard to leader R\&D ratio': $s=\frac{X_{2}}{X_{1}}$ (with $0<s<1$ ). The higher is $s$, the smaller the technology gap between leader and laggard.

Firms can transfer knowledge internally from parent to subsidiary and vice versa. These internal knowledge transfers cross national boundaries and are hence international in scope. These internal transfers are imperfect, not only because of the costs associated with transferring knowledge internationally within the firm, but also because of the need to adapt the transferred know-how to local conditions (see also Sanna-Randaccio \& Veugelers (2001)). Adaptation costs arise from the fact that the products and processes developed by the parent need to be modified to satisfy requirements in the host country. The greater the similarity between the two markets, the smaller will be the need for adaptation. For analytical convenience, we assume symmetry between the two firms and countries in terms of internal transfer efficiency. The internal transfer efficiency is indicated by the parameter $\beta$ $(0<\beta<1)$, representing the share of knowledge that 'survives' if transferred intra-firm across countries.

External knowledge spillovers between the two firms are geographically bounded, and assumed to occur only between headquarters and subsidiaries located in the same country. This is in line with the agglomeration literature, which has inter-firm external knowledge dissemination requiring geographic proximity, (e.g. Gersbach \& Schmutzler, 1999). External spillovers are determined by technology specific factors (such as the complexity of know-how affecting the degree of appropriation, and the effectiveness of the legal appropriation regime 
for specific technologies), or by country specific factors (the strength of IPR protection). Spillovers are bi-directional: a firm benefits from incoming spillovers if it co-locates $R \& D$, but this will also increase outgoing spillovers to the rival firm. We assume initially that there is symmetry between the two firms and countries in terms of external spillovers, but we will relax this assumption in an extension of the model in Section 4. The parameter $\alpha$ represents the share of knowledge that spills over inter-firm from the parent (subsidiary) of firm $i$ to the subsidiary (parent) of firm $j$, or the share of knowledge originating from the subsidiary (parent) of firm $i$ that spills over to the parent (subsidiary) of firm $j$, with $0<\alpha<1$.

The knowledge flows and parameters of the model are summarized in Figure 1. Incoming external spillovers require, and are enhanced, by internal $R \& D$, which provide firms with the 'absorptive capacity' to effective source and use external knowledge. For instance, in case of a foreign subsidiary $i$, the impact of incoming spillovers on the subsidiary's knowledge base depends on the subsidiary's absorptive capacity represented by

its R\&D expenditures, such that $\alpha\left(1-\lambda_{j}\right) X_{j} * \lambda_{i} X_{i}$ is the addition to the knowledge base of the subsidiary due to incoming spillovers. If firms differ in their R\&D resources, the extent to which external spillovers can be effectively sourced $\left(\alpha\left(1-\lambda_{j}\right) X_{j}\right.$ or $\left.\alpha \lambda_{i} X_{i}\right)$ will be firmspecific even though the parameter $\alpha$ is identical across firms. Hence, firms can influence the effectiveness of external knowledge sourcing through their R\&D localization decision.

\section{INSERT FIGURE 1}

Given the above assumptions, the effective knowledge base at the parent level of firm $i$ is given by:

$$
K_{i}^{P}=\left(1-\lambda_{i}\right) X_{i}+\beta\left[\lambda_{i} X_{i}+\alpha\left(1-\lambda_{j}\right) X_{j}^{*} \lambda_{i} X_{i}\right\rfloor+\alpha \lambda_{j} X_{j}^{*}\left(1-\lambda_{i}\right) X_{i}
$$


The effective knowledge base consists of three parts. The first term represents the internal $R \& D$ allocated to the parent (and not to the foreign subsidiary). The second term is the internal knowledge flowing back from the subsidiary of firm $i$ to the parent (reverse intrafirm spillover). It is the combination of the internal knowledge transfer efficiency parameter $\beta$ and the potential knowledge base to transfer, with the latter consisting of the subsidiary's own R\&D and incoming external spillovers in the foreign country (the benefits to the parent from foreign knowledge sourcing). The third term represents incoming external, inter-firm, knowledge spillovers in the home country of firm $i$, originating from the R\&D resources that rival firm $j$ has located abroad to its subsidiary.

The effective knowledge base of the subsidiary is similarly defined as:

$$
K_{i}^{S}=\lambda_{i} X_{i}+\beta\left[\left(1-\lambda_{i}\right) X_{i}+\alpha \lambda_{j} X_{j}^{*}\left(1-\lambda_{i}\right) X_{i}\right]+\alpha\left(1-\lambda_{j}\right) X_{j}^{*} \lambda_{i} X_{i}
$$

The first term represents the internal R\&D resources for the subsidiary, the second term represents internal knowledge transfers from the parent firm to the subsidiary, and the third term is local knowledge sourcing from the rival parent plant. ${ }^{5}$

The R\&D localization ratio $\left(\lambda_{i}\right)$ will affect the effective knowledge base of both the parent and the subsidiary through all three components. It will influence not only the internal R\&D resources available at each plant, but also the internal knowledge transfers and, through the absorptive capacity effect, also the incoming external spillovers. The rival's localization ratio $\left(\lambda_{j}\right)$ will affect the firm's effective knowledge base by influencing the level of potential incoming external spillovers both at home and abroad. 


\section{Optimal levels of R\&D Localization}

Using (1)-(5) we can solve for the optimal value for $\lambda$. The reaction functions of firms 1 and w with respect to their rival's R\&D localization ratio become:

$$
\begin{aligned}
& \lambda_{1}\left(\lambda_{2}\right)=b \alpha s(1-\mu)(1+\beta)\left[1-2 \lambda_{2}\right] / \delta \\
& \lambda_{2}\left(\lambda_{1}\right)=b \alpha(1-\mu)(1+\beta)\left[1-2 \lambda_{1}\right] / s \delta
\end{aligned}
$$

The reaction functions are downward sloping ${ }^{6}: \mathrm{R} \& \mathrm{D}$ localization of firms $i$ and $j$ are strategic substitutes. If firm $i$ increases the share of $R \& D$ resources allocated to its subsidiary, then firm $j$, ceteris paribus, has an incentive to decrease its own share of $\mathrm{R} \& \mathrm{D}$ resources located abroad. This reflects the agglomeration enhancing impact of inter-firm knowledge spillovers: firm $i$ can increase the impact of R\&D resources on its knowledge bases by responding to an increase in foreign $\mathrm{R} \& \mathrm{D}$ by rival firm $j$ (in the home country of firm i) with increased concentration of $R \& D$ resources in its home country. Increasing $R \& D$ at home enhance the firm's absorptive capacity and allows it to benefit more from the expanded sourcing opportunities due to the rival's increase in local R\&D.

The reaction functions are drawn in Figure 2 for a set of reasonable parameter values to which we refer as the 'benchmark case': relatively efficient internal transfers $(\beta=0.8)$, a moderate level of inter-firm knowledge spillovers $(\alpha=0.3)$, an intermediate level of product market competition $(\mu=0.6)$, no strong cost disadvantage of decentralizing $\operatorname{R} \& \mathrm{D}(\delta=0.1)$, clear technological leadership of firm $1(s=0.4)$, and the market scale parameter set at $b=0.8$.

INSERT FIGURE 2 
Solving for the optimal $\lambda$ gives the following expressions for firm 1, the technology leader and for firm 2, the technology laggard: ${ }^{7}$

$$
\begin{aligned}
& \lambda_{1}{ }^{*}=\frac{b \alpha(\beta+1)(1-\mu)[2 b \alpha(1+\beta)(1-\mu)-s \delta]}{\left(4 b^{2} \alpha^{2}(1+\beta)^{2}(\mu-1)^{2}-\delta^{2}\right)} \\
& \lambda_{2}{ }^{*}=\frac{b \alpha(\beta+1)(1-\mu)\left[2 b \alpha(1+\beta)(1-\mu)-\frac{\delta}{s}\right]}{\left(4 b^{2} \alpha^{2}(1+\beta)^{2}(\mu-1)^{2}-\delta^{2}\right)}
\end{aligned}
$$

The optimal localization ratio is a complex function of the model parameters. We examine the impact of the parameters of interest (internal transfer efficiency, the extent of external spillovers, and product market competition) on the optimal value of $R \& D$ localization, distinguishing between the technology leader and the technology laggard. We will examine the comparative statics, but we will also illustrate the results through numerical analysis.

\section{Inter-firm Spillovers $(\alpha)$}

We first examine the impact of the external spillovers parameter $\alpha$ on the share of foreign $\mathrm{R} \& \mathrm{D}$, allowing us to examine the sensitivity of localization decisions with respect to the effectiveness of intellectual property rights protection. For the moment, we assume that this is an industry-wide feature rather than a country-specific feature; in an extension we will relax this assumption.

Comparative static analysis shows that for the technology leader, an increase in external spillovers leads to a reduction in the share of $R \& D$ resources allocated abroad if the 
firms' technology lead is greater than a certain threshold level: $\frac{\partial \lambda_{1}{ }^{*}}{\partial \alpha}<0$ if $s<s_{1}{ }^{8}$ Technology leaders with a large technology advantage (small $s$ ) are less likely to allocate a substantial share of $R \& D$ resources abroad when appropriation is more difficult, since this will allow the laggard to benefit more from knowledge spillovers. Numerical simulations suggest that the condition in some case requires a strong technology gap ( $s_{1}$ ranges between 0.33 and 0.76 ). Conversely, the lagging firm's optimal R\&D localization ratio increases in the spillover intensity if the technology gap with the leader is greater than a certain threshold level: $\frac{\partial \lambda_{2}{ }^{*}}{\partial \alpha}>0$ if $s<s_{2}$, with $s_{2}=1 / s_{1}$. If the leader responds to an increase in spillovers by reducing localization, the laggard is certain to respond by increasing R\&D localization $\left(s<s_{2}\right.$ holds if $s<s_{1}$ ). Numerical simulations furthermore suggest that in the base case and in most alternative parameter settings, the condition $s<s_{2}$ is not binding. The laggard locates more R\&D near the R\&D base of the leader in the leader's home market in order to increase its effective know-how base through external sourcing. Having more R\&D resources abroad improves its absorptive capacity and enhances the scope for overseas knowledge sourcing. Compared to the leader, the laggard has less to fear from outgoing knowledge spillovers since its R\&D budget and the scope for outgoing spillovers is smaller

Result: With larger inter-firm knowledge spillovers, strong technology leaders allocate a larger share of $R \& D$ at home, while technology laggards allocate a larger share of $R \& D$ abroad, c.p.

Figure 3 shows the shift in reaction functions from the base case of parameter settings from Figure 2, as the spillover parameter increases from 0.3 to 0.5 . This leads to an outward shift of 
both reaction functions, resulting in a new equilibrium with lower foreign localization for the leader and higher localization for the follower.

\section{INSERT FIGURE 3}

\section{Efficiency of intra-firm knowledge transfer $(\beta)$}

An increase in the intra-firm knowledge transfer parameter reflects more efficient transfer of knowledge within the firm, e.g. because of better knowledge management practices or information and communication technologies. It can also reflect a reduction in differences in markets between the two countries, reducing the need to adapt knowledge transferred across countries. A high level of $\beta$ facilitates the transfer of home-laboratory knowledge abroad and hence favors centralization of $R \& D$ at home. But at the same time, it increases the incentives for technology sourcing abroad, as knowledge sourced by the subsidiary can be transferred back to benefit parent firm operations more easily.

It can be shown that under strong technology leadership conditions, the first effect dominates and hence more efficient internal technology transfers lead to centralization of R\&D at home by the leader: $\frac{\partial \lambda_{1}^{*}}{\partial \beta}<0$ if $s<s_{1}$. Conversely, under the same circumstances:

$\frac{\partial \lambda_{2}^{*}}{\partial \beta}>0$ if $s<s_{2} ;$ the laggard allocates more $\mathrm{R} \& \mathrm{D}$ resources abroad. This foreign $\mathrm{R} \& \mathrm{D}$ allows the laggard to benefit from more reverse transfer of foreign sourced knowledge, an effect which is more important for the laggard than for the leader. ${ }^{9}$ 
Result: If intra-firm international knowledge transfers are more efficient, strong technology leaders allocate a larger share of $R \& D$ abroad at home, while technology laggards allocate a larger share of $R \& D$ abroad, c.p.

Figure 4 shows for the base case of parameter settings, how reaction functions shift as the transfer parameter increases from 0,8 to 0,95 . This leads to an outward shift of both reaction functions resulting in a new equilibrium with lower localization for the leader and higher localization for the follower.

\section{INSERT FIGURE 4}

\section{Intensity of Product Market Competition ( $\mu$ )}

The product market competition parameter $\mu$ is an indicator of the effect of the rival firm's knowledge base on the firm's profitability. Higher values of $\mu$ indicate a greater intensity of strategic interaction between the two firms. It can be shown that the derivative of $\mathrm{R} \& \mathrm{D}$ localization of the leader with respect to the competition parameter is positive as long as

the technology gap between leader and laggard is sufficiently large: $\frac{\partial \lambda_{1}^{*}}{\partial \mu}>0$ if $s<s_{1}$. Increased product market competition makes the leader more aggressive in the rival's home market and leads to a larger incentive for $R \& D$ decentralization to capture a larger share of profits in the foreign market, which is possible because of the weakness of the local rival in its home market. This effect is stronger than the detrimental impact of increased outgoing external spillovers in the foreign market with stronger product market competition. For the 
laggard, increased product market competition leads to a response to defend its home market position by keeping more R\&D resources at home: $\frac{\partial \lambda_{2}{ }^{*}}{\partial \mu}<0$ if $s<s_{2}$.

Result: With increased product market competition, strong technology leaders allocate a larger share of $R \& D$ abroad, while technology laggards allocate more $R \& D$ at home, c.p.

Figure 5 shows how the base case reaction functions change as the competition parameter increases from 0,6 to 0,75 . The leader's reaction function becomes flatter while the follower's becomes steeper, resulting in a new equilibrium with increased localization for the leader and decreased localization for the follower.

INSERT FIGURE 5

Intensity of Product Market Competition and inter-firm Spillovers: $\mu$ and $\alpha$

Another interesting feature that can be studied with the model is the interaction between the intensity of external spillovers and the intensity of competition. One would expect that the larger incentive of the leader to engage in strategic foreign $R \& D$ would be reduced if localization increases the risk of knowledge dissipation, e.g. due to a weakly developed intellectual property rights regime. This result can be shown to hold under the condition of a relatively large technology gap: $\frac{\partial^{2} \lambda_{1}^{*}}{\partial \mu \partial \alpha}<0$ if $s<s_{3}$. Hence, weak appropriability conditions due to ineffective IPR protection reduces the impact of competition 
on decentralizing R\&D resources for the leader. For the follower: $\frac{\partial^{2} \lambda_{2}^{*}}{\partial \mu \partial \alpha}>0$ if $s<s_{4}$ with $s_{4}=1 / s_{3}$. The follower will allocate less $\mathrm{R} \& \mathrm{D}$ at home in response to increased competition if inter-firm spillovers are large. ${ }^{10}$

Result: The positive impact of product market competition on the share of $R \& D$ located abroad by the technology leader is reduced when inter-firm spillovers are larger, c.p. Similarly, greater inter-firm spillovers reduce the positive impact of product market competition on the share of $R \& D$ located at home by the technology laggard, c.p.

Numerical analysis shows that for reasonable parameters settings the threshold $s_{4}$ exceeds one, hence the cross derivative is always positive. Simulations also show that the threshold value $s_{3}$ does not reach levels below 0.6 , such that $\frac{\partial^{2} \lambda_{1}^{*}}{\partial \alpha \partial \mu}<0$ holds under relatively mild conditions concerning technological leadership.

\section{Introducing Different national IPR Regimes}

A factor favoring centralization of research activities by MNEs is the increased risk of knowledge dissipation when firms decentralize these activities in foreign countries, especially when rival MNEs operate in the host country. Although localization of R\&D abroad increases the firm's ability to source knowledge from foreign competitors, at the time it also increases the possibility of knowledge dissipation to the local rivals. We can expect that a MNE will be reluctant to localize R\&D in a foreign country where the IPR protection is 
relatively weak, in which case the unwanted knowledge flows to local rivals will deter $\mathrm{R} \& \mathrm{D}$ decentralization. Conversely a host economy, looking to attract inward R\&D, may benefit from a tightening of its IPR regime relative to other countries.

In order to take account of the effect of country-specific IPR protection on MNEs' R\&D localization decisions, we relax the assumptions of the model to allow for different external spillover parameters in each country. We can either have $\alpha_{1}<\alpha_{2}$, which reflects the case of stronger IPR protection in the home country of the technology leader, or $\alpha_{1}>\alpha_{2}$, which reflects the case of stronger IPR protection in the host country of the technology leader. For analytical clarity, we prefer the R\&D localisation decision to be affected by differences in IPR regimes in the different countries and not by the level of R\&D spillovers per se. Therefore, we assume that in case of differences in IPR protection (spillovers), the same 'on average' IPR protection in both cases: $\alpha=\frac{\alpha_{1}+\alpha_{2}}{2}$, with $\alpha_{1}<\alpha<\alpha_{2}$. With a country specific external spillover parameter, the reaction function of firm 1 is:

$$
\lambda_{1}\left(\lambda_{2}\right)=b s(1-\mu)(1+\beta)\left[\alpha_{2}-\left(\alpha_{1}+\alpha_{2}\right) \lambda_{2}\right] / \delta
$$

while the optimal share of $R \& D$ allocated abroad for firm 1 is given by:

$$
\left(\lambda_{1}^{*}\right)^{\prime}=\frac{b(\beta+1)(1-\mu)\left[b(1+\beta)(1-\mu) \alpha_{1}\left(\alpha_{1}+\alpha_{2}\right)-s \delta \alpha_{2}\right]}{\left(b^{2}(1+\beta)^{2}(\mu-1)^{2}\left(\alpha_{1}+\alpha_{2}\right)^{2}-\delta^{2}\right)}
$$

In a first scenario the technology leader is based in a country where the IPR regime is stronger. This could reflect the case of a technology leading MNE based in a developed country (such as the US), competing with a technology lagging MNE based in a newly developing country, with the developed country typically having stronger IPR regimes than 
the newly developing country (such as China). Comparing the optimal value of the share of R\&D resources decentralized for firm 1 in (7.1') with the base case of no differences in $\alpha$ (equation 7.1), it is easy to see that if $\alpha_{1}<\alpha_{2}$, then $\left(\lambda_{1}{ }^{*}\right)^{\prime}<\lambda_{1}{ }^{*}$. In the case of stronger IPR protection in the leader's home market, the optimal value of the share of the leader's R\&D located abroad $\left(\lambda_{1}^{*}\right)$ is lower. Since $R \& D$ decentralization increases the probability of knowledge dissipation, the leader is more reluctant to locate $R \& D$ in the foreign market where IPR protection is weaker. Similarly it can be seen that if $\alpha_{1}<\alpha_{2},\left(\lambda_{2}^{*}\right)^{\prime}>\lambda_{2}{ }^{*}$ Hence, for the follower firm the opposite holds, and the optimal value of the share of foreign $\operatorname{R} \& D\left(\lambda_{2}^{*}\right)$ increases. The tendency of the leader to centralize R\&D at home drives the follower's actions. The follower increases the share of $R \& D$ decentralized in order to benefit from increased sourcing opportunities in the leader's country since more knowledge is concentrated in that country, even though this country has the stricter IPR regime.

Result: With stronger IPR protection (lower inter-firm spillovers) in the technology leader's country, the technology leader allocates a larger share of $R \& D$ at home, while the technology laggard allocates a larger share of $R \& D$ abroad, c.p.

In Figure 6 we compare the equilibrium outcomes under the two different cases: the initial model where spillovers have the same magnitude in both countries and the model in which spillovers are stronger in country 2. The initial reaction functions $\left(\lambda_{1}\left(\lambda_{2}\right)\right.$ and $\left.\lambda_{2}\left(\lambda_{1}\right)\right)$ are drawn in Figure 6 for the base case set of parameter values as in Figure 2, while the reaction functions corresponding to the different-spillover-parameter case $\left(\lambda_{1}^{\prime}\left(\lambda_{2}\right)\right.$ and $\left.\lambda_{2}^{\prime}\left(\lambda_{1}\right)\right)$ are drawn for the same set of parameter values with $\alpha_{1}=0.25$ and $\alpha_{2}=0.35$ instead of 
$\alpha=0.3$. The graph shows that the equilibrium with $\alpha_{1}<\alpha_{2}$ is characterized by lower $\mathrm{R} \& \mathrm{D}$ decentralization by the leader and higher R\&D decentralization by the follower.

\section{INSERT FIGURE 6}

A second scenario that can be considered is the case in which weaker IPR protection characterizes the home market of the leader. Comparing the optimal value of the share of

$\mathrm{R} \& \mathrm{D}$ resources decentralized for each firm we find that if $\alpha_{1}>\alpha_{2}$, then $\left(\lambda_{1}^{*}\right)^{\prime}>\lambda_{1}^{*}$ and $\left(\lambda_{2}{ }^{*}\right)^{\prime}<\lambda_{2}{ }^{*}$. If spillovers are larger in the leader's country, the optimal value of the share of leader's $R \& D$ localized abroad $\left(\lambda_{1}^{*}\right)$ increases and the optimal share of R\&D located abroad for the laggard decreases. Hence the leader's R\&D localization decision appear strongly sensitive to differences in IPR regimes, due to the need to reduce outgoing knowledge spillovers to the lagging rival. The action of the laggard again is driven by the leader's decision to decentralize more $R \& D$ abroad: the laggard keeps more $R \& D$ abroad to defend its home market and to benefit to an extent from the increased R\&D activities performed by the leader there. This scenario could for instance be related to the situation in the pharmaceutical industry where EU technology leading MNEs are increasingly localizing part of their research in the US market which is characterized by relatively stronger and more clear IPR protection in the biotech area.

Result: With stronger IPR protection (lower inter-firm spillovers) in the laggard's country, the technology leader allocates a larger share of $R \& D$ abroad, while the technology laggard allocates a larger share of $R \& D$ at home, c.p. 
The reaction functions for the parameter values $\alpha_{1}=0.35$ and $\alpha_{2}=0.25$ are drawn in Figure 7 and compared to the base case of $\alpha=0.3$. The reactions function of the laggard shifts up and the reaction function of the leader shifts down, leading to a larger share of $R \& D$ decentralization by the leader and a lower share of R\&D decentralization by the follower.

\section{INSERT FIGURE 7}

We conclude that independently of the technology lead, when country-specific spillover parameters are introduced into the model, we always see an R\&D agglomeration effect in the country with the stronger IPR protection. This suggests that IPR regimes can be used as a policy tool to attract foreign $R \& D$ and at the same time keep own R\&D in the country.

\section{Conclusions}

This paper analyzes strategic interactions in $R \& D$ internationalization by a multinational firm facing competition of a rival multinational both abroad and in its home market. In allocating $R \& D$ resources abroad, the firm may benefit from incoming R\&D spillovers due to R\&D performed in the local market by the rival multinational (technology sourcing). On the other hand, the firm also faces greater risk of dissipation of know-how from its own R\&D investments abroad to its rival. Alternatively, the firm can rely primarily on parent firm $R \& D$ and transfer knowledge intra-firm to its overseas operations. The model takes into account the 'two faces' of R\&D: the positive impact on absorptive capacity increasing the benefits of incoming spillovers, as well as the direct positive effect on the firm's knowledge base. The decision to perform part of R\&D abroad in turn affects the trade off between home and host 
country $R \& D$ faced by the rival firm, with localization decisions of the rival multinationals strategic substitutes. In equilibrium, the shares of $R \& D$ performed abroad depend on the importance of spillovers, the strength of product market competition, the efficiency of intrafirm transfers, and whether the firm is a technology leader (defined in terms of the size of R\&D investments) or a technology laggard.

Results show the different incentives faced by technology leaders and technology laggards in the decision to locate R\&D abroad. Greater efficiency of intra-firm transfers leads to a greater reliance on home market R\&D by technology leaders if the gap with laggards is sufficiently large. This outcome confirms results of earlier work on R\&D localization in the context of a single multinational's R\&D localization decision (e.g. Norback, 2001). Laggards in contrast perform more $R \& D$ abroad in this case, because their home market operations can benefit more from overseas technology sourcing. Greater R\&D spillovers (e.g. due to a weaker effectiveness of intellectual property rights for the industry) have a similar impact, reducing overseas $R \& D$ by leaders due to appropriability concerns, but increasing overseas R\&D by laggards due to the technology sourcing motive. Greater intensity of product market competition encourages the leading firm to engage in foreign $R \& D$ to make use of its technology advantage and to capture a larger share of the local market. Laggards in contrast, are more likely to concentrate $R \& D$ at home to defend their home market position. These effects are smaller if the leader faces more serious risks of dissipation of knowledge due to higher levels of inter-firm knowledge spillovers. If country-specific IPR protection regimes are introduced in the model, the results confirm the reluctance of multinational firms to localize $R \& D$ in countries with weak IPR regimes, as found in empirical evidence presented by e.g. Branstetter et al, 2003. The model suggests that independently of the technology lead, R\&D by both leader and laggard tends to agglomerate in the country with the stronger IPR protection. 
Future work in this direction could bring the model closer to empirical settings by introducing market asymmetry in combination with firm asymmetry. A more complex extension would be to allow for endogenous determination of the size of R\&D budgets and to fully specify the characteristics of product market competition. Another avenue for future analysis on $R \& D$ internationalization is to test the prediction of the model on data on $R \& D$ localization strategies in settings where multinationals from different countries invest in each others' home markets.

\section{References}

Almeida, P., 1996, Knowledge Sourcing by Foreign MNEs: Patent Citation Analysis in the US Semiconductor Industry, Strategic Management Journal, 155-165

Audretsch, D. and M. Feldman, 1996, R\&D spillovers and the geography of innovation and production', American Economic Review, 86, 630-40.

Belderbos, R.A., 2001 Overseas Innovations by Japanese Firms: An Analysis of Patent and Subsidiary Data, Research Policy, Vol. 30 (2), 313-332.

Belderbos, R. A., 2003 Entry Mode, Organizational Learning, and R\&D in Foreign Affiliates: Evidence from Japanese Firms, Strategic Management Journal, 24 (3), 235-259.

Belderbos, R.A., K Fukao, and T. Iwasa, 2005, Domestic and Foreign R\&D Investment, Working Paper, Hitotsubashi University.

Bjorvatn K. and C. Eckel, 2001: 'Technology Sourcing and Foreign Direct Investment', Norwegian School of Economics Discussion Paper n. 28/01. 
Branstetter, L. G., 2000, Is Foreign Direct Investment a Channel of Knowledge Spillovers: Evidence from Japan's FDI in the United States, NBER working paper 8015, NBER, Cambridge, $M A$.

Brantstetter, L G., R. Fisman, and C. F. Foley et al, 2004, Do Stronger Intellectual Property Rights Increase International Knowledge Transfer? Empirical Evidence from U.S. FirmLevel Panel Data, Working paper.

Cabral, L., 2003, R\&D competition when firms choose variance, Journal of Economics and Management Strategy, 12, 139-150.

Cassiman, B., D. Pérez-Castrillo and R. Veugelers, 2002, Endogenizing know-how flows through the nature of $\mathrm{R} \& \mathrm{D}$ investments, International Journal of Industrial Organization, 20 (6), 775-799.

Cohen, W. and D. Levinthal, 1989, Innovation and learning: the two faces of R\&D, Economic Journal, 569-96.

Cadot, O., D. Desruelle, 1998, R\&D: who does the R, who does the D?, Journal of International Economics, 46, 87-103.

Florida, R., 1997, The Globalization of R\&D: Results of Survey of Foreign-Affiliated R\&DLaboratories in the USA, Research Policy, 26, 85-102.

Franck, B. and Owen, R, 2003, Fundamental R\&D Spillovers and the Internationalization of a Firm's Research Activities, Cowles Foundation Discussion Paper, No. 1425.

Frost, A., 1998, The geographic sources of innovation in the multinational enterprise: US subsidiaries and host country spillovers, 1980-1990, PhD Sloan School of Management, MIT.

Frost, Thomas, 2001, The geographic sources of foreign subsidiaries' innovation, Strategic Management Journal, 22, 101-124. 
Jaffe, Adam B; Trajtenberg, Manuel; and Henderson, Rebecca, 1993, Geographic Localization of Knowledge Spillovers as Evidenced by Patent Citations, Quarterly Journal of Economics, August 1993, 108(3), pp. 577-598

Gersbach and Schmutzler, 1999, External Spillovers, Internal Spillovers and the Geography of Production and Innovation, Regional Science and Urban Economics, 29 (6), 679-696.

Griffith, Rachel, Rupert Harrison, and John van Reenen, 2003, Technology sourcing by UK Manufacturing firms: an empirical analysis using firm-level patent data, working paper, Institute of Fiscal Studies, London.

Iwasa, Tomoko; Odagiri, Hiroyuki, 2004, Overseas R\&D, knowledge sourcing, and patenting: an empirical study of Japanese R\&D investment in the US, Research Policy, 33 (5), 807-829.

Kuemmerle, W., 1997, Building Effective R\&D Capabilities Abroad, Harvard Business Review, March / April, 61-70.

Kuemmerle, W., 1999, The Drivers of Foreign Direct Investment into Research and Development: an Empirical Investigation, Journal of International Business Studies, 30(1), 1-24.

Kumar, N., 1996, Intellectual property protection, market orientation and location of overseas R\&D activities by multinational enterprises, World Development 24: 673-688.

Leahy, D. and P. Neary (1999): 'Absorptive capacity, R\&D spillovers and public policy', University College Dublin, Economics Dept, mimeo.

Le Bas, C. and C. Sierra, 2002, Location versus home country advantages in R\&D activities: some further results on multinationals locational strategies, Research Policy, 31, 589609.

Lee, J. Y. and E. Mansfield, 1996, Intellectual Property Rights Protection and U.S. Foreign Direct Investment, Review of Economics and Statistics, 79: 181-186. 
Ministry of Economics, Trade and Industry (2003), Kaigai Toushi Tokei Souran (Basic Survey on Foreign Direct Investment), Tokyo.

Norback, P.-J., 2001, Multinational firms, technology and location, Journal of International Economics, 54, 449-69.

Odagiri H. and Yasuda H., 1996, The determinants of overseas R\&D by Japanese firms: an empirical study at the industry and company levels, Research Policy 25: 1059- 1079.

OECD, 2005, Background report to the Conference on "Internationalisation of R\&D", Brussels, March.

Petit M.L. and F. Sanna-Randaccio, 2000, Endogenous R\&D and Foreign Direct Investment in International Oligopolies, International Journal of Industrial Organization, 18, 339367.

Reger, G., 2001, Differences in the Internationalization of Research and Technology between Western European, Japanese and North American Companies, mimeo, Univ of Brandenburg.

Sanna-Randaccio F. and R. Veugelers, 2001, Multinational Knowledge Spillovers with Centalized vs Decentralized R\&D, CEPR discussion paper, n. DP3151.

Siotis, G., 1999, Foreign Direct Investment Strategies and Firm Capabilities, Journal of Economics and Management Strategy, 8, 251-270.

Slaughter, M., 2004, Insourcing Jobs: Making the global economy work for America, BEA report

Smarzynska, Beate, 2004, Composition of Foreign Direct Investment and Protection of Intellectual Property Rights: Evidence from Transition Economies, European Economic Review, vol. 18 (1), 39-62. 
Zedtwitz, M. Von, and Gassmann, O. (2002): Market versus Technology Drive in R\&D Internationalization: Four Different Patterns of Managing Research and Development, in: Research Policy, Vol. 31, 2002, No. 4, 569-588

Zejan, M., 1990, R\&D Activities in Affiliates of Swedish Multinational Firms, Scandinavian Journal of Economics, Vol. 92, No 3, pp. 487-500. 


\section{APPENDIX}

\section{Existence of Equilibrium:}

For the existence of equilibrium, the slope of $\lambda_{1}\left(\lambda_{2}\right)$ has to be smaller than the slope of $\lambda_{2}\left(\lambda_{1}\right)$, and the intercept of $\lambda_{1}\left(\lambda_{2}\right)$ has to be greater than the intercept of $\lambda_{2}\left(\lambda_{1}\right)$. Both conditions lead to an identical expression:

$$
\delta<2 b \alpha(1-\mu)(1+\beta) s
$$

Equilibrium requires that the costs of decentralization are not prohibitive compared to the magnitude of the impact of $R \& D$ and knowledge stocks on profits (the scale parameter $b$ ). Condition A.1 will hold as long as the two markets are not too small, allowing profitable decentralized R\&D.

\section{Threshold Values for Derivatives}

The threshold values for the derivatives of the optimal localization ratio with respect to $\beta, \alpha$, and $\mu$ are:

$$
s_{1}=\frac{4 \alpha b \delta(1+\beta)(1-\mu)}{\delta^{2}+4 b^{2} \alpha^{2}(1+\beta)^{2}(\mu-1)^{2}}=\frac{1}{s_{2}}
$$

The threshold values for the cross derivative of the optimal localization ratio with respect to $\alpha$ and $\mu$ jointly are:

$$
s_{3}=\frac{8 b \alpha \delta(1+\beta)(1-\mu)\left[4 b^{2} \alpha^{2}(1+\beta)^{2}(1-\mu)^{2}+\delta^{2}\right]}{\delta^{4}+16 b^{2} \alpha^{2}(1+\beta)^{2}(\mu-1)^{2}\left[2 \delta^{2}+b^{2} \alpha^{2}(1+\beta)^{2}(\mu-1)^{2}\right]}=\frac{1}{s_{4}}
$$




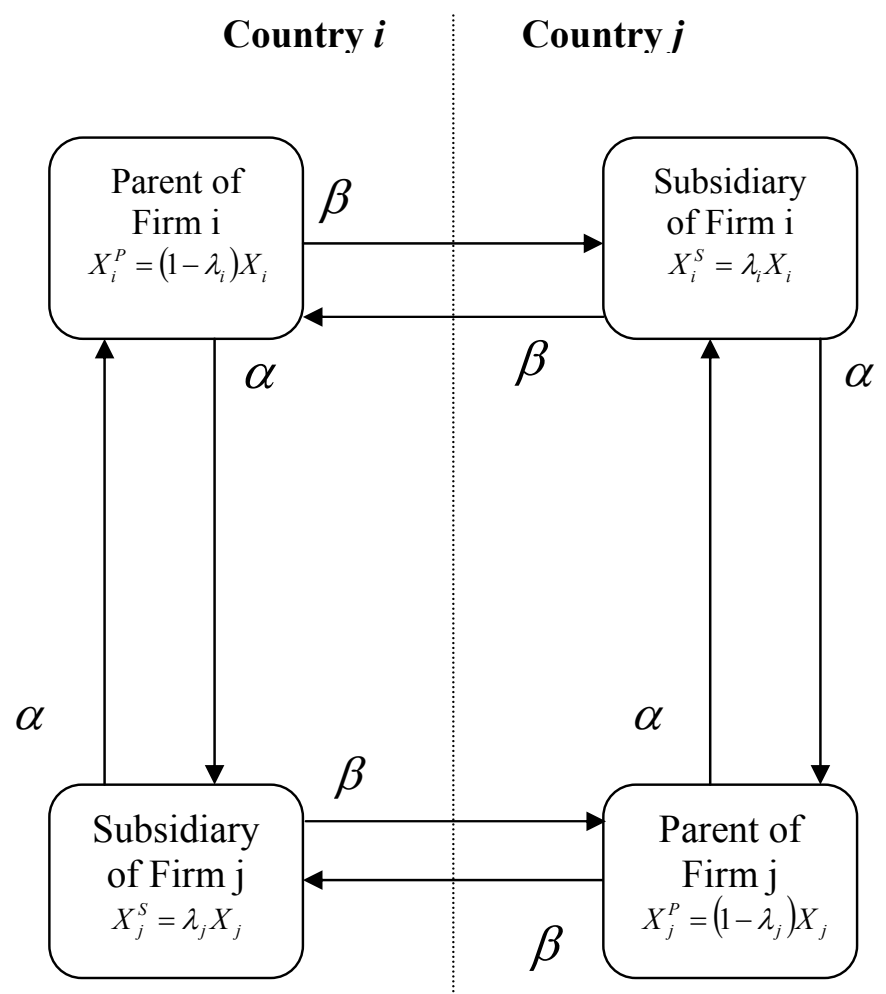

Figure 1: Internal knowledge transfers and external knowledge snillovers 

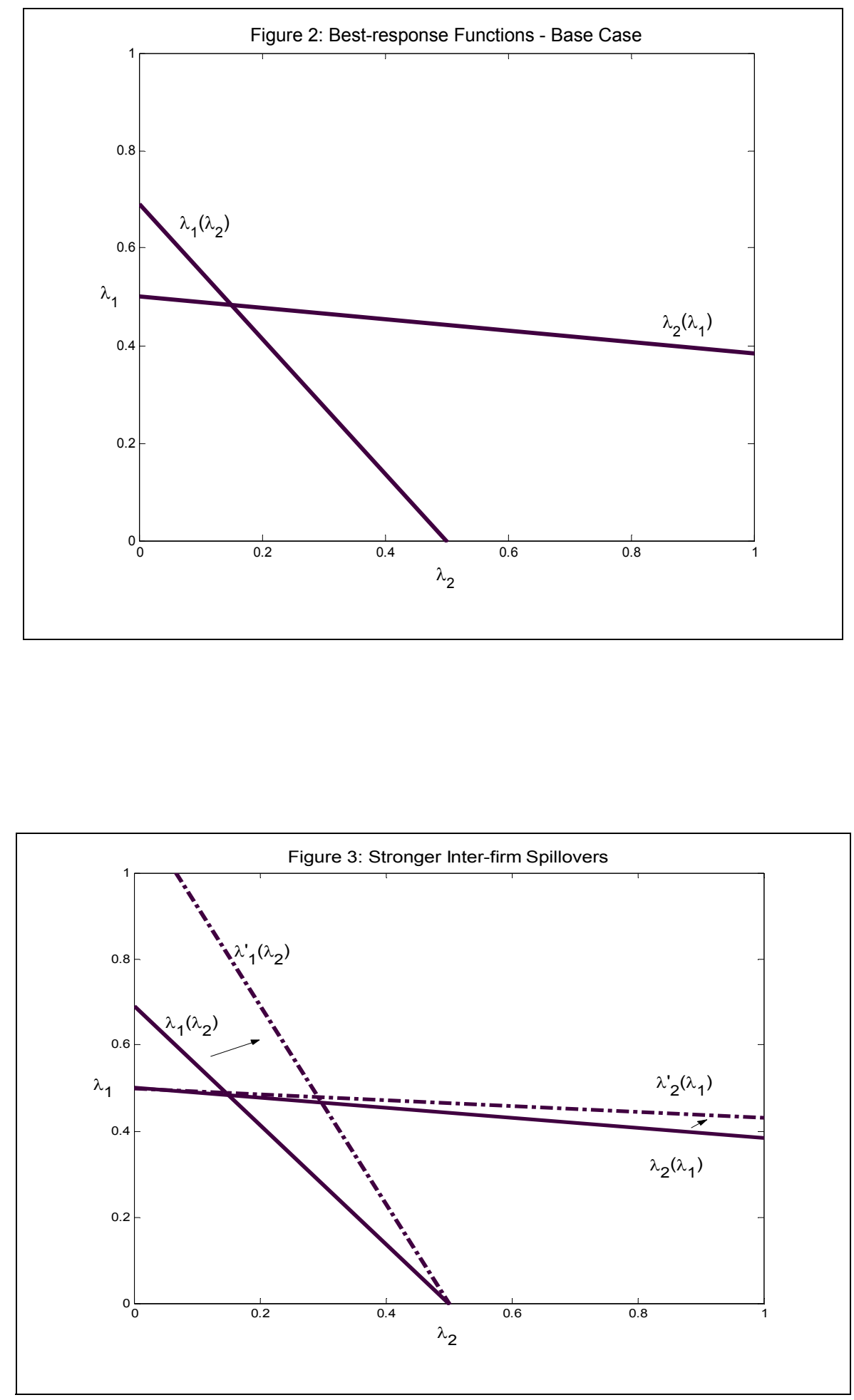

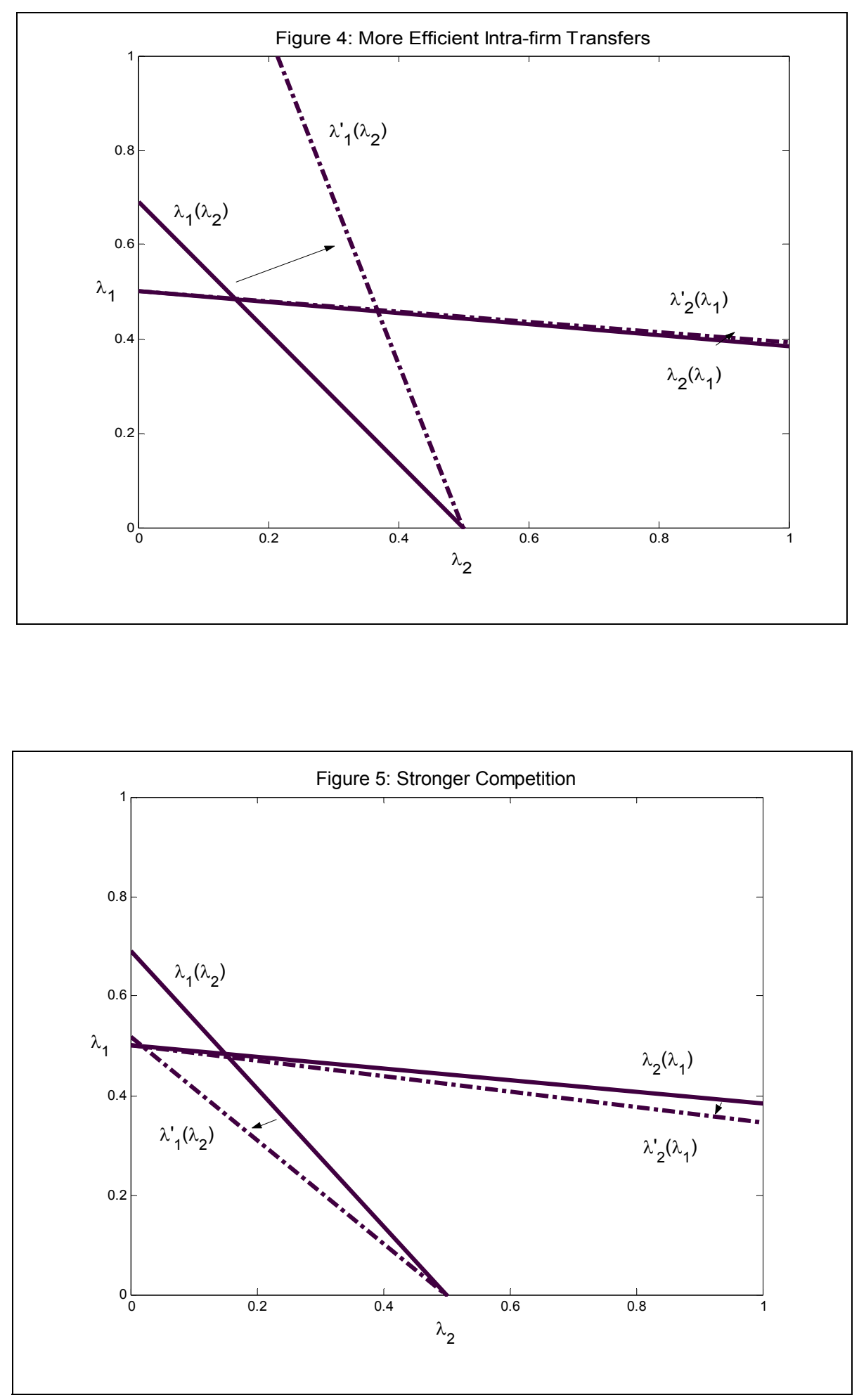

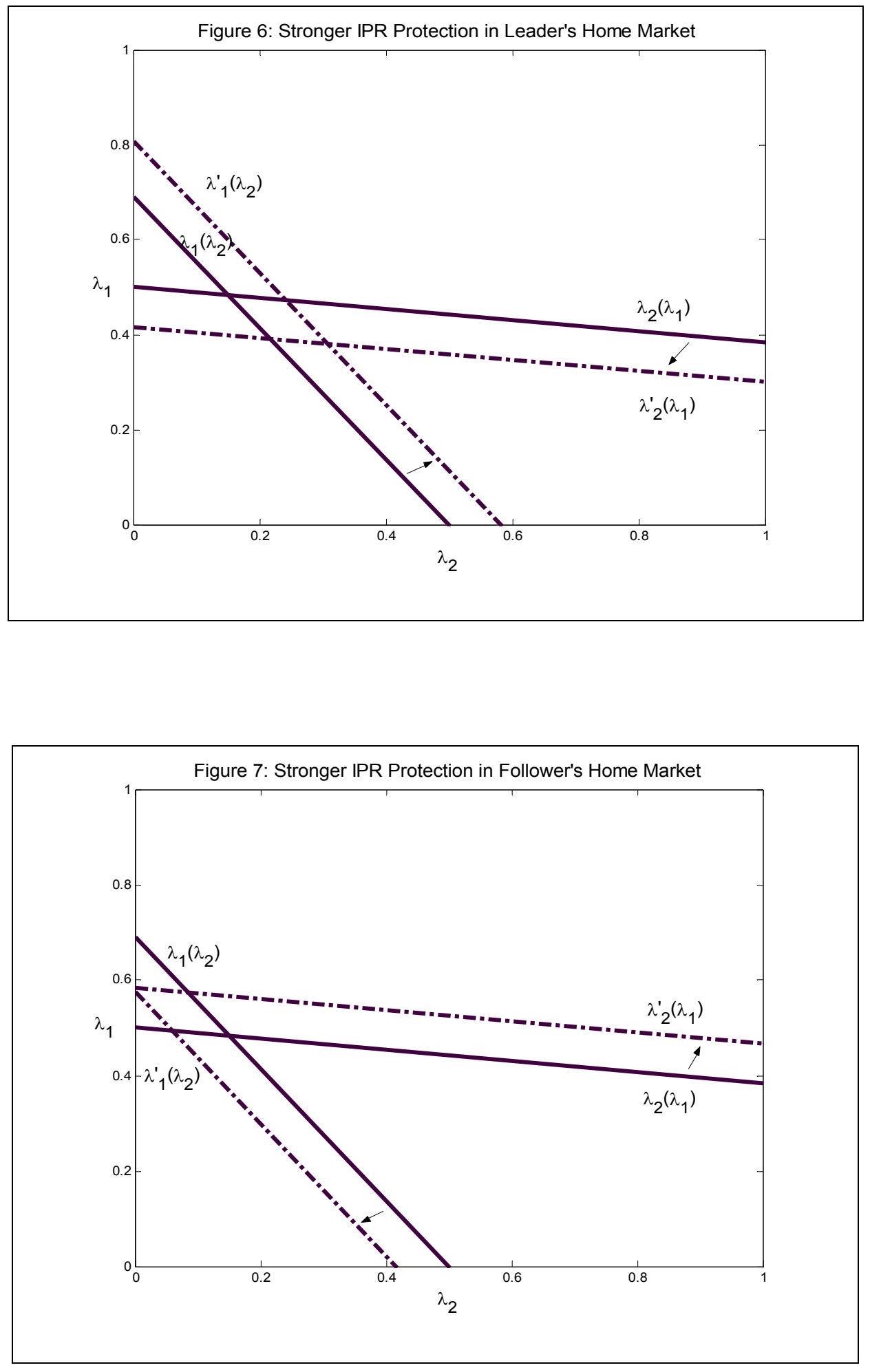
${ }^{1}$ See, e.g. Cohen and Levinthal (1989), Leahy and Neary (1999), and Cassiman et al. (2003).

${ }^{2}$ These findings relate to a larger body of literature on the degree of localization of spillovers and know-how (e.g. Audretsch and Feldman, 1996). Jaffe et al. (1993) found that being close to an external information source increases the impact of spillovers from that source on internal technological capabilities and know-how.

${ }^{3}$ Fosfuri (2000) assumes that while the licensee may decide to imitate, exports \& FDI can perfectly prevent such imitation. He finds that if imitation is possible, e.g. because of a lower degree of patent protection in the host country, firms may prefer to choose exports or FDI, to license the older technology for which there are less incentives to imitate.

4 The literature has amply dealt with the determination of size of the R\&D budget by MNEs (e.g. Petit and Sanna Randaccio, 2000). In this paper, we treat the R\&D budget as given and focus on the related choice of the location of R\&D. In view of the high adjustment costs, particularly in personnel recruitment, firms often take their R\&D budgets as fixed at least in the short run, considering the decision on how to spend the R\&D resources rather than the decision on how much to spend (e.g. Cabral, 2003).

${ }^{5}$ To keep the model tractable, we assume that only internal R\&D is a source of potential outgoing local spillovers, and not the knowledge available in the subsidiary due to internal transfers from the parent. This implies that the MNE can influence inter-firm spillovers through its decentralization decision, with centralization of R\&D in the home country reducing the scope for outgoing inter-firm spillovers.

${ }^{6}$ This is obvious, as $b \alpha s(1-\mu)(1+\beta)$ is positive.

${ }^{7}$ The conditions for existence of equilibrium are given in the Appendix.

${ }^{8}$ The precise expression of these and other threshold levels are provided in the Appendix.

${ }^{9}$ The role of the size of the technology gap can also be shown by the cross derivative of localization with respect to the internal transfer parameter and the technology gap parameter $s$. It can be shown that increasing the gap (a smaller $s$ ) increases the negative impact of $\beta$ on the localization of the leader, and decreases the positive impact of $\beta$ on the localization of the follower $; \frac{\partial^{2} \lambda_{1}^{*}}{\partial \beta \partial s}>0$ and $\frac{\partial^{2} \lambda_{2}^{*}}{\partial \beta \partial s}<0$

${ }^{10}$ The cross derivates can also be interpreted as showing that the positive impact of a looser appropriation regime on the follower's decision to locate $R \& D$ resources abroad is reinforced when product market competition is stronger. Similarly, stronger product market competition reinforces the negative impact of a looser appropriation regime on the leader's decision to locate R\&D resources abroad. 